\title{
HUBUNGAN ANTARA USIA, BODY MASS INDEX DAN JENIS KELAMIN DENGAN OSTEOPOROSIS
}

\author{
Sri Andarini ${ }^{\star \bowtie}$, Bagus Putu Putra Suryana**, Dewangga Wahyu Praja***
}

\begin{abstract}
Abstrak
Osteoporosis adalah penyakit tulang sistemik yang ditandai dengan massa tulang yang rendah dan kerusakan mikroarsitektur jaringan tulang yang mengakibatkan peningkatan kerapuhan tulang. Osteoporosis paling sering terjadi pada bagian femoral neck dan lumbar spine (L1-L4). Terdapat beberapa faktor risiko penyebab osteoporosis seperti usia, body mass index (BMI) dan jenis kelamin. Penelitian ini bertujuan untuk membuktikan kontribusi usia, BMI dan jenis kelamin berhubungan dengan terjadinya osteoporosis pada femoral neck dan lumbar spine (L1-L4). Penelitian ini menggunakan desain potong lintang. Populasi penelitian adalah seluruh pasien yang datang dan diperiksa di Poliklinik Osteoporosis RSUD. Dr. Saiful Anwar Malang berdasarkan rekam medis pada tahun 2012. Sampel diambil secara total sampling yaitu sebanyak 154 pasien. Peneltian ini menunjukkan bahwa faktor usia berhubungan dengan terjadinya osteoporosis pada lumbar spine (L1-L4) $(p=0,018)$, sedangkan BMI berhubungan dengan osteoporosis pada femoral neck $(p=0,000)$. Hasil analisis multiple logistic regression menunjukkan bahwa usia, BMI, dan jenis kelamin dapat memprediksi terhadap terjadinya osteoporosis pada femoral neck $\left(\mathrm{R}^{2}=\right.$ $0,155)$, dan osteoporosis pada lumbar spine (L1-L4) $\left(R^{2}=0,112\right)$. Dapat disimpulkan bahwa faktor usia berpengaruh terhadap osteoporosis pada lumbar spine (L1-L4) dan BMI berpengaruh terhadap osteoporosis femoral neck. Usia, BMI dan jenis kelamin secara bersama-sama berpengaruh terhadap osteoporosis femoral neck dan lumbar spine (L1-L4).
\end{abstract}

Kata kunci: body mass index, jenis kelamin, osteoporosis, usia.

\section{THE RELATIONSHIP AMONG AGE, BODY MASS INDEX, AND SEX WITH OSTEOPOROSIS}

\begin{abstract}
Osteoporosis is a systemic skeletal disease characterized by low bone mass and destruction of bone tissue microarchitecture resulting in increased bone fragility. The most common site of osteoporosis is in the femoral neck and lumbar spine (L1-L4). Some risk factors that can lead to osteoporosis such as age, body mass index, and sex. The purpose of this study is to assess the contribution of age, body mass index, and sex to osteoporosis at the femoral neck and lumbar spine (L1-L4). This study used a cross-sectional study. The sample was secondary data from the medical records of osteoporosis patients at Osteoporosis Clinic of Public Hospital Dr. Saiful Anwar Malang in 2012 as many as 154 patients. The results showed the relationship of age with osteoporosis at the lumbar spine (L1-L4) $(p=0.018)$, but BMI had a relationship with osteoporosis at the femoral neck $(p=0.000)$. Moreover, the multiple logistic regression were revealed that age, BMl, and sex influence the occurrence of osteoporosis at the femoral neck $\left(\mathrm{R}^{2}=0.155\right)$, and lumbar spine (L1-L4) $\left(R^{2}=0.112\right)$. In conclusion, age has an effect on osteoporosis at the lumbar spine (L1-L4) and the BMl affects femoral neck osteoporosis. Yet age, BMI, and sex together have an effect on osteoporosis at the femoral neck and lumbar spine (L1-L4).
\end{abstract}

Keywords: age, body mass index, osteoporosis, sex.

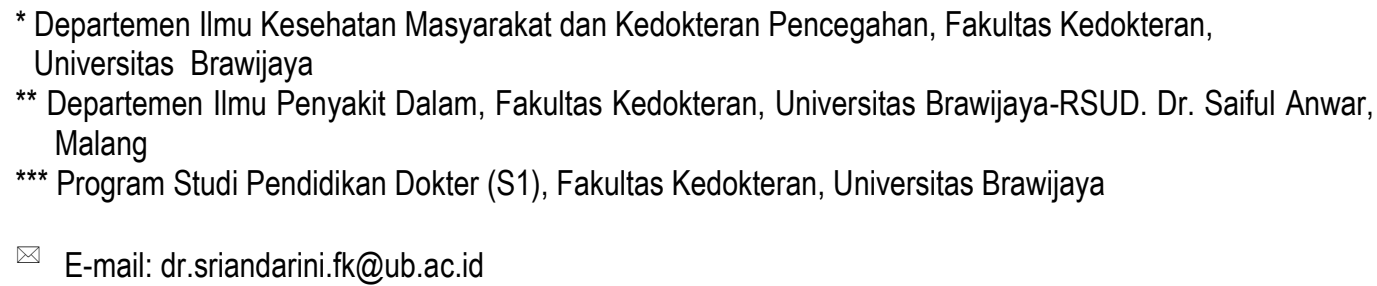




\section{Pendahuluan}

Osteoporosis adalah penyakit tulang sistemik yang ditandai dengan massa tulang yang rendah dan kerusakan mikroarsitektur jaringan tulang yang mengakibatkan peningkatan kerapuhan tulang. ${ }^{1}$ Osteoporosis dapat disebabkan karena kegagalan membangun tulang dan kegagalan mencapai puncak massa tulang pada masa dewasa muda serta pengeroposan tulang di kemudian hari. ${ }^{2}$

Prevalensi osteoporosis di Amerika Serikat baik di leher femur dan tulang belakang lumbar adalah $9 \%$, yang terdiri dari $4 \%$ dengan osteoporosis pada tulang belakang lumbar saja, $3 \%$ dengan osteoporosis pada leher femur saja, dan $2 \%$ dengan osteoporosis baik pada lumbar tulang belakang dan leher femur. Prevalensi massa tulang yang rendah di kedua situs rangka adalah $49 \%$, yang terdiri dari $10 \%$ dengan massa tulang yang rendah di tulang belakang lumbal, 22\% dengan massa tulang yang rendah pada leher femur, dan $17 \%$ dengan massa tulang yang rendah pada kedua lumbar tulang belakang dan leher femur. ${ }^{3}$ Puncak massa tulang dapat dicapai pada usia 30-34 tahun dan rata-rata kehilangan massa tulang pasca menopause adalah $1,4 \%$ /tahun. ${ }^{4}$

Terdapat beberapa faktor risiko yang dapat menyebabkan osteoporosis seperti usia, BMl dan jenis kelamin. Fraktur osteoporotik akan meningkat seiring dengan bertambahnya usia. ${ }^{4}$ Bertambahnya usia merupakan faktor yang dapat menyebabkan osteoporosis karena pada individu yang berusia lebih dari 50 tahun, setiap tahunnya kehilangan sekitar $5 \%$ dari massa tulang. ${ }^{5}$ Berdasarkan data Sistem Informasi Rumah Sakit (SIRS) tahun 2010, angka insiden patah tulang paha atas tercatat sekitar 200/100.000 kasus pada wanita dan pria di atas usia 40 tahun diakibatkan osteoporosis. ${ }^{6}$ Sembilan persen orang dewasa di atas usia 50 tahun menderita osteoporosis baik pada leher femur atau tulang belakang lumbar, dan kira-kira satu setengah memiliki massa tulang yang rendah pada salah satu dari dua lokasi skelet ini. Osteoporosis dapat menyebabkan risiko terjadinya patah tulang. ${ }^{3}$

Pengaruh jenis kelamin terhadap kejadian osteoporosis dapat diamati pada perempuan yang memiliki risiko fraktur dua kali lebih besar dibandingkan laki-laki pada usia yang sama. ${ }^{4}$ Wanita lebih rentan terkena osteoporosis karena terjadi penurunan hormon esterogen terutama saat menopause. ${ }^{5}$ Penurunan hormon seks pada pria juga dapat menyebabkan osteoporosis. ${ }^{7}$ Proses remodeling tulang ini sebagian besar dimonitor oleh faktor-faktor endokrin yang berasal dari luar tulang seperti vitamin $\mathrm{D}$, hormon paratiroid, calcitonin, hormon pertumbuhan $(\mathrm{HGH})$, testosterone dan estrogen. ${ }^{7}$ Pada pria dengan hypogonadism akan terjadi penurunan esterogen yang menyebabkan kehilangan massa tulang. ${ }^{8}$

Namun, terdapat kontroversi kasus osteoporosis yang berhubungan dengan body mass index. Sebuah hasil penelitian menunjukkan bahwa BMI lebih rendah merupakan faktor risiko terjadinya BMD rendah yang dapat menyebabkan osteoporosis. ${ }^{9}$ Namun, penelitian lain menjelaskan bahwa obesitas berkaitan dengan penurunan massa tulang yang dapat meningkatkan risiko osteoporosis terutama pada bagian lumbar spine. ${ }^{10}$

Data epidemiologi tentang osteoporosis di Indonesia masih sangat langka. ${ }^{11}$ Indonesia memiliki jumlah penduduk sekitar 237 juta jiwa dan diperkirakan 71 juta orang akan berusia lebih dari 60 tahun pada tahun $2050.12 \mathrm{Hal}$ ini berkontribusi pada tingginya angka osteoporosis. ${ }^{11}$ Oleh karena itu, penyediaan informasi tentang faktor risiko osteoporosis sangat penting untuk mencegah dari kejadian osteoporosis. Penelitian ini dilakukan untuk membuktikan hubungan antara usia, body mass indexd an jenis kelamin dengan kejadian osteoporosis pada femoral neck dan lumbar spine (L1-L4). 


\section{Bahan dan Metode}

\section{Desain Penelitian}

Untuk mencapai tujuan penelitian yakni menjelaskan hubungan antara usia, body mass index dan jenis kelamin dengan terjadinya osteoporosis pada femoral neck dan lumbar spine (L1-L4), maka digunakan desain potong lintang.

\section{Lokasi Penelitian}

Penelitian ini dilakukan di Poliklinik Osteoporosis Rumah Sakit Umum Daerah Dr. Saiful Anwar Malang.

\section{Populasi dan Sampel Penelitian}

Seluruh sampel yang diperiksa dengan parameter osteoporosis di Rumah Sakit Umum Daerah Saiful Anwar Malang pada tahun 2012 yaitu 154 pasien yang berusia 6170 tahun.

\section{Prosedur Pengambilan Data}

Data subjek diambil dari rekam medis pasien dengan cara memilihnya berdasarkan kriteria inklusi yaitu jenis kelamin pasien (perempuan dan laki-laki) dan usia dewasa ( $\geq$ 40 tahun). Pasien pengidap penyakit kronik seperti tuberkulosis, sirosis hati, kanker dan diabetes mellitus dikeluarkan dari penelitian ini (kriteria eksklusi). Kemudian, mencatat usia, body mass index (BMI) dan jenis kelamin pasien. Selain itu, dilakukan juga pencatatan T-score pada femoral neck dan lumbar spine (L1-L4) dengan diagnosis osteoporosis adalah $t$-score $<-2,5$.

\section{Analisis Data}

Analisis data menggunakan uji chisquare $\left(\mathrm{x}^{2}\right)$ dan multiple logistic regression dengan menggunakan software SPSS for Windows versi 16.0 .

\section{Hasil}

Berdasarkan data yang dikumpulkan dari Poliklinik Osteoporosis Rumah Sakit Umum Daerah Dr. Saiful Anwar Malang tahun 2012, terdapat 154 penderita osteoporosis berusia dalam rentang 61-70 tahun. Sampel diambil dari 154 rekam medis pasien dengan osteoporosis pada femoral neck dan lumbar spine (L1-L4). Pada saat penelitian, dilakukan pengambilan data dengan mencatat usia, body mass index $\left(\mathrm{kg} / \mathrm{m}^{2}\right)$ dan jenis kelamin.

Pada distribusi frekuensi dan karakteristik pada Tabel 1 diketahui bahwa 154 penderita osteoporosis terdapat 19 orang atau sekitar $12 \%$ berusia $40-50$ tahun, 40 orang atau sekitar $26 \%$ berusia dalam rentang 51-60 tahun, 49 orang atau sekitar $32 \%$ berusia $61-70$ tahun, 37 orang atau sekitar 24\% berusia 71-80 tahun, dan 9 orang atau sekitar $6 \%$ berusia 81-90 tahun

Ada 5 kategori body mass index menurut Depkes RI, yaitu kurus sekali, kurus, normal, gemuk dan gemuk sekali. 6 Dari 5 kategori tersebut didapatkan bahwa mayoritas pasien osteoporosis berdasarkan data yang diperoleh dari rekam medis pasien osteoporosis di Poliklinik Osteoporosis Rumah Sakit Umum Daerah Saiful Anwar Malang pada tahun 2012 masuk ke dalam kategori normal $\left(18,5-27,0 \mathrm{~kg} / \mathrm{m}^{2}\right)$.

Dari 154 penderita osteoporosis yang ada di rekam medis, 136 penderita osteoporosis atau sekitar $88 \%$ pasien osteoporosis pada tahun 2012 adalah perempuan. Pasien berjenis kelamin laki laki sebanyak 18 orang atau sekitar $12 \%$ dari 154 penderita osteoporosis.

Berdasarkan data diketahui pasien osteoporosis di daerah femoral neck adalah 14 orang $(9 \%)$ dari 154 penderita osteoporosis. Sedangkan 140 orang (91\%) sisanya tidak terkena osteoporosis pada femoral neck. Jumlah pasien osteoporosis di daerah lumbar spine (L1-L4) adalah 45 orang (29\%) dari 154 penderita osteoporosis. Sedangkan 109 orang (71\%) sisanya tidak terkena osteoporosis pada lumbar spine (L1L4). 
Pada Tabel 2 diketahui bahwa usia tidak memiliki hubungan dengan osteoporosis pada femoral neck, akan tetapi usia memiliki hubungan dengan osteoporosis pada lumbar spine (L1-L4). Selain itu, BMI memiliki hubungan dengan osteoporosis pada femoral neck, akan tetapi BMl tidak memiliki hubungan dengan ostepororosis pada lumbar spine (L1-L4). Faktor jenis kelamin juga tidak menunjukkan hubungan dengan osteoporosis pada femoral neck maupun pada lumbar spine (L1-L4)

Sementara itu, pada Tabel 3 diketahui bahwa usia, BMI dan jenis kelamin mempunyai pengaruh yang signifikan terhadap terjadinya osteoporosis pada femoral neck dan osteoporosis pada lumbar spine (L1-L4).

Tabel 1. Distribusi frekuensi dan karakteristik penderita osteoporosis.

\begin{tabular}{|c|c|}
\hline Karakteristik & Jumlah $(n=154)(\%)$ \\
\hline \multicolumn{2}{|l|}{ Usia } \\
\hline $40-50$ tahun & $19(12 \%)$ \\
\hline $51-60$ tahun & $40(26 \%)$ \\
\hline $61-70$ tahun & $49(32 \%)$ \\
\hline $71-80$ tahun & $37(24 \%)$ \\
\hline $81-90$ tahun & $9(6 \%)$ \\
\hline \multicolumn{2}{|l|}{ BMI } \\
\hline$\left(\mathrm{BMI} 25,1-27,0 \mathrm{~kg} / \mathrm{m}^{2}\right)$ & $25(16 \%)$ \\
\hline Gemuk sekali $\left(\mathrm{BMI}>27 \mathrm{~kg} / \mathrm{m}^{2}\right)$ & $28(18 \%)$ \\
\hline Kurus $\quad$ (BMI $\left.17.0-18.4 \mathrm{~kg} / \mathrm{m}^{2}\right)$ & $10(7 \%)$ \\
\hline Kurus sekali $\quad\left(B M I<17 \mathrm{~kg} / \mathrm{m}^{2}\right)$ & $5(3 \%)$ \\
\hline \multicolumn{2}{|l|}{ Normal $\quad\left(B M I 18,5-25,0 \mathrm{~kg} / \mathrm{m}^{2}\right)$} \\
\hline \multicolumn{2}{|l|}{ Jenis Kelamin } \\
\hline Laki-laki & $18(12 \%)$ \\
\hline Perempuan & $136(88 \%)$ \\
\hline \multicolumn{2}{|l|}{ Osteoporosis pada femoral neck } \\
\hline Ya $\quad($ T-score $\leq-2,5)$ & $14(9 \%)$ \\
\hline Tidak (T-score > 2,5) & $140(91 \%)$ \\
\hline \multicolumn{2}{|l|}{ Osteoporosis pada lumbar spine L1-L4 : } \\
\hline \multirow{2}{*}{ Ya (T-score $\leq-2,5)$} & $45(29 \%)$ \\
\hline & $109(71)$ \\
\hline
\end{tabular}

Tabel 2. Analisis chi square dari usia, BMI, dan jenis kelamin terhadap osteoporosis pada femoral neck dan lumbar spine (L1-L4).

\begin{tabular}{ll}
\hline \multicolumn{1}{c}{ Variabel } & \multicolumn{1}{c}{ Nilai $\mathrm{p}$} \\
\hline Usia terhadap osteoporosis femoral neck & 0,061 \\
Usia terhadap osteoporosis L1-L4 & $0,018^{*}$ \\
BMI terhadap osteoporosis femoral neck & $0,000^{*}$ \\
BMl terhadap osteoporosis L1-L4 & 0,053 \\
Jenis kelamin terhadap osteoporosis femoral neck & 0,234 \\
Jenis kelamin terhadap osteoporosis L1-L4 & 0,487 \\
\hline
\end{tabular}

Keterangan: *Nilai $p(\mathrm{sig})<0,050$ berarti ada perbedaan yang bermakna. 
Tabel 3. Hasil multiple logistic regression dari usia, BMI, dan jenis kelamin terhadap osteoporosis pada femoral neck dan lumbar spine (L1-L4).

\begin{tabular}{llccc}
\hline \multicolumn{1}{c}{ Osteoporosis } & Variabel & Wald & Nilai $p$ & Nilai R \\
\hline Femoral neck & usia, BMl, dan jenis kelamin & 66,550 & $0,000^{*}$ & 0,155 \\
Lumbar spine (L1-L4) & usia, BMI, dan jenis kelamin & 25,207 & $0,000^{*}$ & 0,112
\end{tabular}

Keterangan: *Nilai $p($ sig) $<0,050$ berarti ada perbedaan yang bermakna.

\section{Pembahasan}

Pada usia lebih dari 60 tahun terjadi peningkatan angka kejadian osteoporosis pada lumbar spine (L1-L4). Hal ini menunjukkan bahwa usia merupakan faktor risiko terjadinya osteoporosis. Seiring bertambahnya usia, maka seseorang akan semakin rentan terkena osteoporosis terutama pada usia di atas 40 tahun seperti yang disampaikan oleh Depkes Republik Indonesia pada tahun 2012. 6 Lebih lanjut lagi, Hirsch dan Walsh pada tahun 2012 mengemukakan bahwa bertambahnya usia merupakan faktor yang dapat menyebabkan osteoporosis karena pada individu yang berusia lebih dari 50 tahun, setiap tahunnya kehilangan sekitar $5 \%$ dari massa tulang yang dapat menyebabkan osteoporosis. ${ }^{5}$

Berdasarkan hal di atas, maka pada penelitian ini didapatkan batas terendah usia menggunakan usia 40 tahun dan selanjutnya akan dikategorikan menjadi 5 kategori (lihat Tabel 1) untuk memudahkan pengelompokan data. Dari data pada Tabel 1 dapat disimpulkan bahwa usia dapat menyebabkan terjadinya osteoporosis. Pada penelitian ini, usia berhubungan dengan kejadian osteoporosis pada lumbar spine (L1-L4). Namun, usia tidak berhubungan terhadap kejadian osteoporosis pada femoral neck. Usia adalah faktor risiko yang tinggi pada kejadian osteoporosis. Hal ini disebkan oleh ketidakcukupan vitamin $D$ dan menurunnya penyerapan kalsium pada lansia. ${ }^{13}$

Hasil penelitian ini juga menunjukkan bahwa mayoritas BMI pada rekam medis pasien osteoporosis pada tahun 2012 berkategori normal $\left(18,5-25 \mathrm{~kg} / \mathrm{m}^{2}\right)$. Akan tetapi, yang berpotensi untuk terkena osteoporosis terutama pada femoral neck adalah BMI dengan kategori kurus sekali $(<17$ $\mathrm{kg} / \mathrm{m}^{2}$ ). Sejalan dengan Fawzy dkk pada tahun 2011 yang menyatakan bahwa BMI rendah merupakan faktor risiko penting untuk terjadinya BMD rendah yang dapat menyebabkan osteoporosis. ${ }^{9}$ Hal ini bertolak belakang dengan pendapat Greco pada tahun 2010 yang menyebutkan bahwa obesitas memiliki asosiasi dengan penurunan massa tulang yang dapat berakibat terhadap terjadinya osteoporosis. ${ }^{10}$

BMI memiliki hubungan terhadap kejadian osteoporosis pada femoral neck. Hal ini sejalan dengan hasil penelitian Wu dan Du (2016) yang menunjukkan bahwa berat badan, tinggi badan, dan BMI secara spesifik berkorelasi positif dengan kejadian BMD pada lumbar vertebra (L1-L4), femoral neck, proximal femur, dan Ward's triangle region $(P$ $<0,05) \cdot{ }^{14}$ Beberapa penelitian sebelumnya juga menyimpulkan bahwa peningkatan BMI juga berhubungan dengan peningkatan level BMD. ${ }^{15,16,17}$ Adanya hubungan tersebut dapat disebabkan oleh berat badan tinggi akan berakibat pada remodelling tulang untuk mengimbangi beban mekanis yang berat. 17,18 Akan tetapi, pada penelitian ini didapatkan bahwa kejadian osteoporosis pada lumbar spine (L1-L4) tidak memiliki hubungan yang bermakna dengan BMI. Hal ini terjadi karena pada data penderita osteoporosis pada tahun 2012 di Rumah Sakit Umum Daerah Saiful Anwar Malang didapatkan sedikitnya angka kejadian dari osteoporosis pada lumbar spine (L1-L4). 
Dari data rekam medis yang didapat pada tahun 2012, sekitar 88\% pasien osteoporosis di Rumah Sakit Dr. Saiful Anwar Malang berjenis kelamin perempuan. Sejalan dengan penelitian Hirsch \& Walsh pada tahun 2012 bahwa wanita lebih rentan terkena osteoporosis karena pada fase menopause akan terjadi penurunan hormon esterogen pada perempuan. ${ }^{5}$ Pada fase menopause, proses pembentukan tulang terganggu karena menurunnya estrogen. Hal ini karena adanya reseptor estrogen di sel-sel progenitor osteoklas dan multi-nucleated osteoclasts sehingga meningkatkan aktifitas penyerapan osteoklas dan menurunkan aktifias osteoblas yang berakibat pada penurunan massa tulang. ${ }^{19}$

Akan tetapi, menurut hasil penelitian di atas, jenis kelamin tidak memiliki hubungan yang signifikan terhadap kejadian osteoporosis pada femoral neck maupun dengan kejadian osteoporosis pada lumbar spine (L1-L4). Hal ini karena data perempuan yang terkena osteoporosis pada femoral neck dan lumbar spine (L1-L4) lebih sedikit dibandingkan dengan yang terkena osteoporosis pada femoral neck dan lumbar spine (L1-L4).

Dari total 136 perempuan, hanya 11 orang yang terkena osteoporosis pada femoral neck dan 125 orang tidak terkena osteoporosis pada femoral neck. Sedangkan pada osteoporosis lumbar spine (L1-L4), dari 136 perempuan terdapat 41 orang yang terkena osteoporosis pada lumbar spine (L1L4) dan 95 orang tidak terkena osteoporosis pada lumbar spine (L1-L4).

Pada penelitian ini terdapat keterbatasan karena menggunakan data sekunder yaitu rekam medis pasien osteoporosis pada tahun 2012. Selain itu, variabel pengganggu seperti genetik, faktor lingkungan, hormon endogen, aktifitas individu dan penyakit kronik tidak dilakukan karena tidak tercantum pada rekam medis pasien

\section{Kesimpulan}

Penelitian ini menyimpulkan bahwa usia berhubungan signifikan terhadap kejadian osteoporosis pada lumbar spine (L1-L4). BMI berhubungan signifikan terhadap kejadian osteoporosis pada femoral neck. Mayoritas BMI pada rekam medis pasien osteoporosis pada tahun 2012 berkategori normal (18,5-25 $\mathrm{kg} / \mathrm{m}^{2}$ ). Jenis kelamin tidak berhubungan signifikan terhadap kejadian osteoporosis pada femoral neck maupun dengan kejadian osteoporosis pada lumbar spine (L1-L4). Usia, BMI, dan jenis kelamin secara bersama sama berpengaruh signifikan terhadap terjadinya osteoporosis pada femoral neck dan osteoporosis pada lumbar spine (L1-L4).

\section{Daftar Pustaka}

1. Ahmed SF and Elmantaser M. Secondary Osteoporosis. Endocr Dev. 2009; 16:90170.

2. Jacobs-Kosmin D. Osteoporosis. H. S. Diamond (Editor). (Online). 2012. Diakses dari http://emedicine.medscape.com/ article/330598clinical\#a0256.

3. Looker AC, Borrud LG, Dawson-Hughes $B$, Shepherd JA, and Wright NC. Osteoporosis or Low Bone Mass at the Femur Neck or Lumbar Spine in Older Adults: United States, 2005-2008. NCHS Data Brief. 2012; (93):1-8.

4. Setiyohadi B. Buku Ajar IImu Penyakit Dalam. Di dalam: Sudoyo AW, Setiyohadi B, Alwi I, MSK, dan Setiati S (Editor). Buku Ajar IImu Penyakit Dalam. Edisi Ke-5. Jakarta Pusat: Interna Publishing. 2009. HIm. 2650-2676.

5. Hirsch JA and Walsh MC. Osteopenia and Osteoporosis: Is There a Difference? (online). 2012. Diakses dari: http:// www.spineuniverse.com/conditions/ osteoporosis/osteopeniaosteoporosisthere -difference. (13 November 2013). 
6. Departemen Kesehatan Republik Indonesia. Kemenkes RI Ajak Masyarakat Lakukan Pencegahan Osteoporosis. (Online). 2012. Diakses dari: http:// www.depkes.go.id/index.php? $\mathrm{vw}=2 \& \mathrm{id}=2083$. (21 Juni 2013)

7. Hoey NV. Adding New Tools and Treatments to Disease Management. Pharm Con Inc. 2011; 1-11.

8. National Institutes of Health. Osteoporosis in Men. (Online). 2012. Diakses dari: https://www.bones.nih.gov/. (13 November 2012).

9. Fawzy T, Muttappallymyalil J, Shreedaran J, Ahmed, A, Alshamsi SO, Ali MS et al. Association between Body Mass Index and Bone Mineral Density in Patients Referred for Dual-Energy X-Ray Absorptiometry Scan in Ajman, UAE. Journal of Osteoporosis. 2011; 2011: 876309.

10. Greco E, Fornari R, Rossi F, Santiemma $V$, Prossomariti $G$, Annoscia $C$ et al. Is Obesity Protective for Osteoporosis? Evaluation of Bone Mineral Density in Individuals with High Body Mass Index. Int J Clin Pract. 2010; 64(6):817-20. doi: 10.1111/j.1742-1241.2009.02301.x

11. Prihartini $S$, Mahirawati VK, Jahari $A B$, and Sudiman $H$. Faktor Determinan Resiko Osteoporosis di Tiga Provinsi di Indonesia. Media Litbang Kesehatan. 2010; XX(2):1-9.

12. Mithal A. The Asian Audit: Epidemiology, Costs and Burden of Osteoporosis in Asia 2009. International Osteoporosis Foundation. 2009. P. 1-60.

13. Jakob F, Seefried L, Schwab M. Age and Osteoporosis. Effects of Aging on Osteoporosis, the Diagnostics and Therapy. Internist. 2014; 55(7):755-61. doi: 10.1007/s00108-014-3468-z.
14. Wu SF and Du XJ. Body Mass Index May Positively Correlate with Bone Mineral Density of Lumbar Vertebra and Femoral Neck in Postmenopausal Females. Med Sci Monit. 2016; 22: 145-151. doi: 10.12659/MSM.895512.

15. Kirchengast S, Peterson B, Hauser G, and Knogler W. Significance of Body Weight Status for Bone Density in the Elderly and Very Old. Zeitschrift für Gerontologie und Geriatrie. 2001; 34 (4):313-318.

16. Doğan A, Nakipoğlu-Yüzer GF, Yıldızgören MT, and Özgirgin N. Is Age or the Body Mass Index (BMI) More Determinant of the Bone Mineral Density (BMD) in Geriatric Women and Men? Archives of Gerontology and Geriatrics. 2010; 51(3):338-341.

17. Hariri AF, Almatrafi MN, Zamka $A B$, Babaker AS, Fallatah TM, Althouwaibi $\mathrm{OH}$, Hamdi AS. Relationship between Body Mass Index and T-Scores of Bone Mineral Density in the Hip and Spine Regions among Older Adults with Diabetes: A Retrospective Review. Journal of Obesity. 2019. Article ID 9827403. 6 pages. https:// doi.org/10.1155/2019/9827403.

18. Wee J, Sng BY, Shen L, Lim CT, Singh $G$, and De SD. The Relationship between Body Mass Index and Physical Activity Levels in Relation to Bone Mineral Density in Premenopausal and Postmenopausal Women. Archives of Osteoporosis. 2013; 8(1-2):162.

19. Lerner UH. Renovasi Tulang pada Osteoporosis Pasca-Menopause. J Dent Res. 2006; 85:584-595. 